\title{
Selection and Assessment of Plant Growth-Promoting Rhizobacteria for Biological Control of Multiple Plant Diseases
}

\author{
Ke Liu, Molli Newman, John A. McInroy, Chia-Hui Hu, and Joseph W. Kloepper
}

Department of Entomology and Plant Pathology, Auburn University, Auburn, AL 36849.

Accepted for publication 24 April 2017.

\begin{abstract}
A study was designed to screen individual strains of plant growthpromoting rhizobacteria (PGPR) for broad-spectrum disease suppression in vitro and in planta. In a preliminary screen, 28 of 196 strains inhibited eight different tested pathogens in vitro. In a secondary screen, these 28 strains showed broad spectrum antagonistic activity to six different genera of pathogens, and 24 of the 28 strains produced five traits reported to be related to plant growth promotion, including nitrogen fixation, phosphate solubilization, indole-3-acetic acid production, siderophore production, and biofilm formation. In advanced screens, the 28 PGPR strains selected in vitro were tested in planta for biological control of multiple plant diseases including bacterial spot of tomato caused by Xanthomonas axonopodis

pv. vesicatoria, bacterial speck of tomato caused by Pseudomonas syringae pv. tomato, damping-off of pepper caused by Rhizoctonia solani, and damping-off of cucumber caused by Pythium ultimum. In all, 5 of the 28 tested strains significantly reduced three of the four tested diseases, and another 19 strains showed biological control to two tested diseases. To understand the observed broad-spectrum biocontrol capacity, antiSMASH was used to predict secondary metabolite clusters of selected strains. Multiple gene clusters encoding for secondary metabolites, e.g., bacillibactin, bacilysin, and microcin, were detected in each strain. In conclusion, selected individual PGPR strains showed broad-spectrum biocontrol activity to multiple plant diseases.
\end{abstract}

Increasing public concern for sustainable agriculture and reduced inputs of pesticides have resulted in renewed interest in beneficial soil microorganisms that can improve soil quality and enhance plant health (Gupta et al. 2015). Plant growth-promoting rhizobacteria (PGPR) are one group of such beneficial microorganisms that has gained interest and is being adopted as inputs in agriculture because some strains both promote plant growth and exhibit biological control of plant diseases (Saharan and Nehra 2011). Biological control using specific PGPR strains has been demonstrated against many plant pathogens (e.g., Pythium spp. (McCullagh et al. 1996), Rhizoctonia solani (Fatima et al. 2009), Fusarium spp. (Yuan et al. 2013), Xanthomonas spp. (Liu et al. 2016), and Pseudomonas spp. (Ji et al. 2006)).

Adoption of biological control agents is growing (Lugtenberg 2014) and was projected to reach five billion dollars by 2020 (Dunham 2016). A key issue faced in the development of PGPR-based biocontrol products is how to select specific strains for use in agriculture. One approach is to select single PGPR strains that exhibit multiple beneficial functions related to crop production and plant growth (Ahmad et al. 2008; Praveen Kumar et al. 2014; Wahyudi and Astuti 2011). Such functions include broad-spectrum biocontrol activity and several mechanisms reported to enhance plant growth directly, such as nitrogen fixation (Bhattacharjee et al. 2008), solubilization of mineral forms of phosphate (Yazdani et al. 2009), secretion of plant hormones (Idris et al. 2007), siderophore production (Sayyed et al. 2013), and biofilm formation (Seneviratne et al. 2011).

Most studies of PGPR as antagonists begin by assessing the efficacy of single PGPR strains against plant pathogens in vitro (Köberl et al. 2013; Kumar et al. 2012) and then using a single PGPR strain against a single plant disease in vivo (Li et al. 2011; Liu et al. 2009). However, in the field, several different diseases often occur on individual crops. Therefore, there is a need to select antagonistic PGPR strains to control multiple plant diseases in vivo. A limited but growing number of

Corresponding author: J. W. Kloepper; E-mail address: kloepjw@auburn.edu

Modified: 12 Dec 2019.

(C) 2017 The American Phytopathological Society broad-spectrum PGPR strains are available commercially, including Kodiak (Bacillus subtilis GB03) for biological control of Rhizoctonia spp., Fusarium spp., and Aspergillus spp.; Integral (B. subtilis MBI 600) for Rhizoctonia spp. and Fusarium spp.; and Serenade (B. subtilis QST 713) for Botrytis spp., Sclerotinia spp., Xanthomonas spp., and Erwinia spp. Product labels list these three strains (GB03, MBI 600, and QST 713 ) as $B$. subtilis. In accordance with recent nomenclatural changes, all of these strains are now classified as B. velezensis (Dunlap et al. 2016).

Biocontrol activity by PGPR strains is often mediated by bacterial secondary metabolites, such as zwittermicin A and kanosamine for biological control of Phytophthora medicaginis by B. cereus strain UW85 (Stabb et al. 1994), fengycin by B. subtilis strain F-29-3 for Rhizoctonia disease (Deleu et al. 2008), and iturin A by B. amyloliquefaciens strain B94 for $R$. solani (Yu et al. 2002). The traditional approach for identifying and characterizing secondary metabolites involves elucidation of the complete chemical structure (Blin et al. 2013; D'aes et al. 2011; Deleu et al. 2008). AntiSMASH using bioinformatics analysis could accelerate this process (Blin et al. 2013). Also, using antiSMASH to predict secondary metabolite clusters would better characterize the genetic determinates directing the biocontrol activity of PGPR strains and provide deeper insights into how biocontrol agents antagonize plant pathogens (Nasrin et al. 2015; Nelson et al. 2014).

The overall aim of this study was to screen a large number of spore-forming bacilli PGPR strains for their broad-spectrum biocontrol activity. The specific objectives were to (i) screen 196 PGPR strains in vitro for phenotypes reported to be related to biological control of multiple plant diseases and multiple traits related to growth promotion, (ii) select individual PGPR strains in vivo for biological control of multiple plant diseases, and (iii) predict the secondary metabolites contributing to the biocontrol phenotype in selected PGPR strains from objective two.

\section{MATERIALS AND METHODS}

Microbial cultures. In this research, a total of 196 PGPR strains were obtained from the PGPR lab at the Department of 
Entomology and Plant Pathology, Auburn University, Alabama. The identity of all strains was determined using 16S rDNA sequencing with comparison with sequences of type strains. The bacteria were maintained in tryptic soy broth (TSB) (Difco Laboratories, Detroit, MI), supplemented with $30 \%$ glycerol at $-80^{\circ} \mathrm{C}$. Inoculum of PGPR was grown on tryptic soy agar (TSA) at $28^{\circ} \mathrm{C}$ for $48 \mathrm{~h}$. A single colony was incubated in $25 \mathrm{ml}$ of TSB with continuous shaking $(150 \mathrm{rpm})$ at $28^{\circ} \mathrm{C}$ for $48 \mathrm{~h}$. The bacterial culture was centrifuged at 3,500 rpm for $15 \mathrm{~min}$. Pellets were resuspended in sterile water, and the concentration was adjusted to $10^{6} \mathrm{CFU} / \mathrm{ml}$.

Twelve phytopathogens from the Phytobacteriology Lab at Auburn University were tested in this study, including Pythium ultimum, Pythium aphanidermatum, Phytophthora capsici, three different isolates of Rhizoctonia solani, Fusarium oxysporum $\mathrm{f}$. sp. lycopersici, F. oxysporum f. sp. vasinfectum, F. virguliforme, Xanthomonas campestris pv. campestris, $X$. axonopodis pv. vesicatoria, and Pseudomonas syringae pv. tomato. The pathogenic fungi were maintained on corn meal agar slants at room temperature for long-term storage and were transferred onto potato dextrose agar (PDA) plates for experimental use. Millet seed inoculum of Pythium ultimum was prepared as described by Howell (2007). Granules of Pythium ultimum inoculum were ground and stored in a sterile container at room temperature. The pathogenic bacteria were stored under the conditions described above and were prepared to $10^{7} \mathrm{CFU} / \mathrm{ml}$ by the same method for experimental use.

Preliminary screen. Each of the 196 PGPR strains were tested for their broad-spectrum antagonistic activity to eight different pathogens in vitro. The antagonism assay was a modified antibiosis technique in which different types of agar were used for the PGPR and the challenged pathogen. Tests were conducted on PDA plates for fungal pathogens and on water agar plates for bacterial pathogens. Three holes of $13 \mathrm{~mm}$ diameter were made into the agar plate, and these were filled with melted TSA. A 10- $\mu$ PGPR suspension was applied to each resulting TSA disk. A 7-mmdiameter disk of the test fungus was placed in the center of the PDA plate for fungal pathogens, and $7 \mathrm{ml}$ of the test bacterial suspension mixed with soft agar (0.4\% Agar in 50\% TSB) was added to the water agar plate for bacterial pathogens. Each plate contained two PGPR strains and a water control. The results were evaluated for the presence or absence of a visible inhibition zone. Eight pathogens were tested in this preliminary screen, including Pythium ultimum, three different isolates of $R$. solani, F. oxysporum f. sp. lycopersici, F. oxysporum f. sp. vasinfectum, $X$. axonopodis pv. vesicatoria, and Pseudomonas syringae pv. tomato. Strains inhibiting the growth of eight pathogens were selected for the secondary screen.

Secondary screen. Twenty-eight PGPR strains selected in the preliminary screen were evaluated in vitro for antagonistic activity to six different genera of pathogens and five traits reported to be related to plant growth promotion. Each of these tests was conducted three times. Strains showing broad-spectrum biocontrol activity and production of multiple traits reported to be related growth promotion were selected for the advanced screen. In the expanded antibiosis test, six pathogens were tested, including Pythium ultimum, Phytophthora capsici, $R$. solani, $F$. virguliforme, $X$. axonopodis pv. vesicatoria, and Pseudomonas syringae pv. tomato. The inhibition zone was measured from the edge of the PGPR strain to the pathogen at the day when the water control reached the edge of the plate.

Five traits related to plant growth were tested, including nitrogen fixation, phosphate solubilization, siderophore production, indole3 -acetic acid (IAA) production, and biofilm formation. Presumptive nitrogen fixation was qualitatively evaluated by growing the PGPR in the nitrogen-free semisolid medium (JNFb) as described by Olivares et al. (1996). Phosphate solubilization was quantitatively performed in three tubes of liquid National Botanical Research Institute's phosphate growth medium (NBRIP), each containing a different phosphate source $\left(\mathrm{Ca}_{3}\left(\mathrm{PO}_{4}\right)_{2}, \mathrm{FePO}_{4}\right.$, and $\left.\mathrm{AlPO}_{4}\right)($ Bashan et al. 2013; Murphy and Riley 1962). Siderophore production was qualitatively evaluated by chrome azurol S medium (Alexander and Zuberer 1991). IAA production was assayed by the quantitative analysis using ferric chloride-perchloric acid reagent $\left(\mathrm{FeCl}_{3}\right.$ $\left.\mathrm{HClO}_{4}\right)$ (Gordon and Weber 1951). Biofilm formation was

TABLE 1. Thirty elite strains (Bacillus and Paenibacillus spp.) inhibiting antibiosis against eight tested pathogens in the preliminary screen

\begin{tabular}{|c|c|c|c|c|c|c|c|c|c|}
\hline Strain & Identify & $\begin{array}{l}\text { Pythium } \\
\text { ultimum }\end{array}$ & $\begin{array}{c}\text { Rhizoctonia } \\
\text { solani (pepper) }\end{array}$ & $\begin{array}{l}R \text {. solani } \\
\text { (lettuce) }\end{array}$ & $\begin{array}{c}R . \text { solani } \\
\text { (zoysia grass) }\end{array}$ & $\begin{array}{c}\text { Fusarium } \\
\text { oxysporum } \\
\text { f. sp. lycopersici }\end{array}$ & $\begin{array}{l}\text { F. oxysporum } \\
\text { f. sp. vasinfectum }\end{array}$ & $\begin{array}{c}\text { Xanthomonas } \\
\text { axonopodis } \\
\text { pv. vesicatoria }\end{array}$ & $\begin{array}{c}\text { Pseudomonas } \\
\text { syringae } \\
\text { pv. tomato }\end{array}$ \\
\hline AP52 & B. velezensis & $+^{\mathrm{z}}$ & + & + & + & + & + & + & + \\
\hline AP69 & B. altitudinis & + & + & + & + & + & + & + & + \\
\hline AP136 & B. velezensis & + & + & + & + & + & + & + & + \\
\hline AP188 & B. velezensis & + & + & + & + & + & + & + & + \\
\hline AP194 & B. velezensis & + & + & + & + & + & + & + & + \\
\hline AP195 & B. velezensis & + & + & + & + & + & + & + & + \\
\hline AP196 & B. velezensis & + & + & + & + & + & + & + & + \\
\hline AP197 & B. velezensis & + & + & + & + & + & + & + & + \\
\hline AP199 & B. velezensis & + & + & + & + & + & + & + & + \\
\hline AP200 & B. velezensis & + & + & + & + & + & + & + & + \\
\hline AP201 & B. velezensis & + & + & + & + & + & + & + & + \\
\hline AP203 & B. velezensis & + & + & + & + & + & + & + & + \\
\hline AP208 & B. velezensis & + & + & + & + & + & + & + & + \\
\hline AP210 & B. velezensis & + & + & + & + & + & + & + & + \\
\hline AP212 & B. velezensis & + & + & + & + & + & + & + & + \\
\hline AP213 & B. velezensis & + & + & + & + & + & + & + & + \\
\hline AP214 & B. velezensis & + & + & + & + & + & + & + & + \\
\hline AP218 & B. velezensis & + & + & + & + & + & + & + & + \\
\hline AP241 & B. velezensis & + & + & + & + & + & + & + & + \\
\hline AP294 & P. peoriae & + & + & + & + & + & + & + & + \\
\hline AP295 & B. velezensis & + & + & + & + & + & + & + & + \\
\hline AP296 & B. velezensis & + & + & + & + & + & + & + & + \\
\hline AP297 & B. velezensis & + & + & + & + & + & + & + & + \\
\hline AP298 & B. velezensis & + & + & + & + & + & + & + & + \\
\hline AP301 & B. velezensis & + & + & + & + & + & + & + & + \\
\hline AP305 & B. velezensis & + & + & + & + & + & + & + & + \\
\hline H57 & B. velezensis & + & + & + & + & + & + & + & + \\
\hline ABU2772 & B. altitudinis & + & + & + & + & + & + & + & + \\
\hline
\end{tabular}

$\mathrm{z}+=$ presence of inhibition zone. 
qualitatively tested in biofilm growth medium (Hamon and Lazazzera 2001; O'Toole et al. 1999).

Advanced screen. Twenty-eight PGPR stains selected in the secondary screen were tested in four groups (group A, group B, group C, and group D); group A with eight strains, group B with six strains, and group C and D with seven strains. Each PGPR group was separately tested for biological control of four different plant diseases, including bacterial spot of tomato caused by

TABLE 2. Inhibition zone ( $\mathrm{mm}$ ) of six tested pathogens by 28 elite plant growth-promoting rhizobacteria (PGPR) strains in the secondary screen

\begin{tabular}{|c|c|c|c|c|c|c|}
\hline Strain & $\begin{array}{l}\text { Pythium } \\
\text { ultimum }\end{array}$ & $\begin{array}{c}\text { Phytophthora } \\
\text { capsici }\end{array}$ & $\begin{array}{l}\text { Rhizoctonia } \\
\text { solani }\end{array}$ & $\begin{array}{c}\text { Fusarium } \\
\text { virguliforme }\end{array}$ & $\begin{array}{l}\text { Xanthomonas } \\
\text { axonopodis } \\
\text { pv. vesicatoria }\end{array}$ & $\begin{array}{c}\text { Pseudomonas } \\
\text { syringae } \\
\text { pv. tomato }\end{array}$ \\
\hline AP52 & $5.3^{\mathrm{z}}$ & 8.7 & 11.7 & 9.7 & 16.0 & 6.7 \\
\hline AP69 & 1.0 & 12.0 & 1.0 & 1.3 & 1.0 & 3.0 \\
\hline AP136 & 4.0 & 7.7 & 11.0 & 9.3 & 14.3 & 6.0 \\
\hline AP188 & 1.0 & 9.3 & 9.3 & 10.7 & 10.0 & 9.3 \\
\hline AP194 & 1.0 & 5.7 & 7.3 & 10.0 & 9.0 & 9.3 \\
\hline AP195 & 1.3 & 6.0 & 9.0 & 10.0 & 13.7 & 6.0 \\
\hline AP196 & 3.0 & 11.3 & 13.3 & 13.0 & 6.3 & 11.7 \\
\hline AP197 & 3.0 & 7.7 & 9.7 & 10.7 & 10.0 & 9.0 \\
\hline AP199 & 5.0 & 11.3 & 4.7 & 9.0 & 16.3 & 8.3 \\
\hline AP200 & 6.0 & 7.0 & 7.3 & 10.7 & 11.7 & 6.0 \\
\hline AP201 & 3.0 & 8.3 & 12.7 & 8.0 & 10.0 & 4.7 \\
\hline AP203 & 2.3 & 11.0 & 10.7 & 7.7 & 9.7 & 4.3 \\
\hline AP208 & 2.3 & 11.0 & 10.7 & 10.3 & 10.3 & 7.0 \\
\hline AP 210 & 1.0 & 9.3 & 11.3 & 9.7 & 12.7 & 6.3 \\
\hline AP212 & 5.3 & 6.7 & 6.3 & 12.3 & 10.3 & 4.7 \\
\hline AP213 & 5.7 & 9.0 & 10.7 & 12.0 & 12.0 & 8.0 \\
\hline AP214 & 5.0 & 10.3 & 12.0 & 11.3 & 12.3 & 7.3 \\
\hline AP218 & 1.3 & 9.0 & 11.0 & 10.7 & 17.7 & 10.7 \\
\hline AP241 & 1.7 & 9.0 & 11.7 & 10.0 & 14.7 & 5.3 \\
\hline AP294 & 4.0 & 15.0 & 7.0 & 3.3 & 1.7 & 1.0 \\
\hline AP295 & 2.7 & 7.3 & 10.7 & 8.7 & 21.3 & 8.3 \\
\hline AP296 & 4.0 & 3.7 & 8.3 & 9.0 & 10.3 & 3.7 \\
\hline AP297 & 2.7 & 7.0 & 9.7 & 8.3 & 15.0 & 12.7 \\
\hline AP298 & 1.0 & 7.3 & 11.3 & 10.3 & 15.3 & 5.7 \\
\hline AP301 & 1.0 & 6.7 & 12.0 & 9.7 & 17.0 & 8.7 \\
\hline AP305 & 1.3 & 9.7 & 7.7 & 10.0 & 19.3 & 12.0 \\
\hline H57 & 1.0 & 7.0 & 8.3 & 9.0 & 15.0 & 14.0 \\
\hline ABU2772 & 1.3 & 19.0 & 11.7 & 1.0 & 9.0 & 14.0 \\
\hline
\end{tabular}

$\mathrm{z}$ The inhibition zone $(\mathrm{mm})$ was measured from the edge of the PGPR strain to the pathogen when water control reached the edge of the plate.

TABLE 3. Characterization of plant growth-promoting rhizobacteria strains for traits reported to be related to plant growth promotion in the secondary screen

\begin{tabular}{|c|c|c|c|c|c|c|c|}
\hline \multirow[b]{2}{*}{ Strain } & \multirow{2}{*}{$\begin{array}{c}\text { Presumptive } \\
\text { nitrogen fixation }{ }^{z}\end{array}$} & \multicolumn{3}{|c|}{ Phosphate solubilization $(\mu \mathrm{g} / \mathrm{ml})$} & \multirow{2}{*}{$\begin{array}{l}\text { Siderophore } \\
\text { production }^{z}\end{array}$} & \multirow{2}{*}{$\begin{array}{c}\text { Indole-3-acetic acid } \\
\text { production }(\mu \mathrm{g} / \mathrm{ml})\end{array}$} & \multirow{2}{*}{$\begin{array}{l}\text { Biofilm } \\
\text { formation }^{\mathrm{z}}\end{array}$} \\
\hline & & $\mathrm{Ca}_{3}\left(\mathrm{PO}_{4}\right)_{2}$ & $\mathrm{FePO}_{4}$ & $\mathrm{AlPO}_{4}$ & & & \\
\hline AP52 & + & 1.8 & 0.0 & 0.0 & + & 9.1 & + \\
\hline AP69 & + & 0.0 & 0.0 & 0.0 & + & 3.0 & + \\
\hline AP136 & + & 1.6 & 0.0 & 0.0 & + & 6.5 & + \\
\hline AP188 & + & 1.1 & 0.1 & 0.0 & + & 6.6 & + \\
\hline AP194 & + & 1.2 & 0.0 & 0.0 & + & 7.2 & + \\
\hline AP195 & + & 0.7 & 0.1 & 0.0 & + & 6.9 & + \\
\hline AP196 & + & 0.0 & 0.0 & 0.0 & + & 7.8 & + \\
\hline AP197 & + & 2.6 & 0.1 & 0.0 & + & 6.7 & + \\
\hline AP199 & + & 1.3 & 0.0 & 0.0 & + & 7.2 & + \\
\hline AP200 & + & 1.3 & 0.0 & 0.0 & + & 8.1 & + \\
\hline AP201 & + & 1.3 & 0.0 & 0.0 & + & 8.3 & + \\
\hline AP203 & + & 1.6 & 0.0 & 0.0 & + & 8.4 & + \\
\hline AP208 & + & 1.2 & 0.0 & 0.0 & + & 8.3 & + \\
\hline AP210 & + & 1.1 & 0.0 & 0.0 & + & 8.1 & + \\
\hline AP212 & + & 1.3 & 0.0 & 0.0 & + & 9.2 & + \\
\hline AP213 & + & 1.1 & 0.0 & 0.0 & + & 8.2 & + \\
\hline AP214 & + & 1.2 & 0.0 & 0.0 & + & 6.0 & + \\
\hline AP218 & + & 1.2 & 0.0 & 0.0 & + & 8.7 & + \\
\hline AP241 & + & 1.3 & 0.1 & 0.0 & + & 5.2 & + \\
\hline AP294 & - & 0.0 & 0.0 & 0.0 & - & 5.5 & - \\
\hline AP295 & + & 1.2 & 0.1 & 0.0 & + & 6.5 & + \\
\hline AP296 & + & 1.4 & 0.0 & 0.0 & + & 6.3 & + \\
\hline AP297 & + & 1.2 & 0.0 & 0.0 & + & 9.5 & + \\
\hline AP298 & + & 1.2 & 0.0 & 0.0 & + & 8.7 & + \\
\hline AP301 & + & 1.3 & 0.0 & 0.0 & + & 8.2 & + \\
\hline AP305 & + & 1.3 & 0.0 & 0.0 & + & 15.0 & + \\
\hline H57 & + & 0.1 & 0.1 & 1.7 & + & 8.6 & + \\
\hline ABU2772 & + & 0.0 & 0.0 & 0.0 & + & 6.4 & + \\
\hline
\end{tabular}

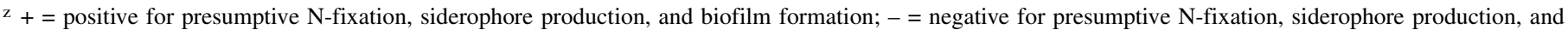
biofilm formation. 
$X$. axonopodis pv. vesicatoria, bacterial speck of tomato caused by Pseudomonas syringae pv. tomato, damping-off of pepper caused by $R$. solani, and damping-off of cucumber caused by Pythium ultimum. In each experiment, treatments (single PGPR strains, a nonbacterized but pathogen-challenged disease control, and a nontreated healthy control) were arranged in a randomized complete block design (RCBD) with six replications. A total of 16 different experiments were conducted in the growth chamber, and each experiment was conducted two or three times. The growth chamber temperature was $24^{\circ} \mathrm{C}$ with a 12 -h photoperiod, and plants were watered daily as needed.

In the test of fungal diseases, $0.62 \mathrm{ml}$ of millet granules of Pythium ultimum or four mycelial plugs $(7 \mathrm{~mm})$ of $R$. solani from the edge of pregrown culture was mixed into $100 \mathrm{ml}$ of commercial potting substrate (Sunshine mix, Sun Gro Horticulture, Agawam, MA). Five seeds of Diva cucumber or California Wonder pepper (Park Seed, Hodges, SC) were placed into the Magenta GA-7 plant culture box $\left(77 \times 77 \times 97 \mathrm{~mm}^{3}\right)$ at $24 \mathrm{~h}$ after pathogen inoculation. One milliliter of PGPR suspension $\left(10^{6} \mathrm{CFU} / \mathrm{ml}\right)$ was applied to each seed prior to covering with $50 \mathrm{ml}$ of potting substrate. Incidence of pre-emergence damping off and of postemergence damping off was recorded at 7 and 14 days after sowing the seed for Pythium ultimum and at 14 and 21 days for $R$. solani.

In the test of bacterial diseases, 'Rutgers Select' tomato seeds (Park Seed, Hodges, SC) were planted in germination trays containing $25 \mathrm{~cm}^{3}$ holes and grown for 3 weeks. Then, seedlings were transplanted into the culture box described above filled with $200 \mathrm{ml}$ of potting substrate. One week after transplanting, plants were sprayed with PGPR suspension $\left(10^{6} \mathrm{CFU} / \mathrm{ml}\right)$ for foliar application. PGPR-inoculated plants were covered with the same culture box to retain humidity. Three days after spraying with PGPR, plants were challenge-inoculated with $X$. axonopodis pv. vesicatoria or Pseudomonas syringae pv. tomato by spraying the whole plant and were covered again by the box. The covered box was removed 4 days after pathogen inoculation. The disease severity was assessed at 7 days after pathogen challenge for bacterial spot and at 10 days for bacterial speck. In the rating of disease, four compound leaves were chosen from the bottom of each

TABLE 4. Selecting individual plant growth-promoting rhizobacteria (PGPR) for biological control of multiple plant diseases in growth chamber bioassays ${ }^{\mathrm{z}}$

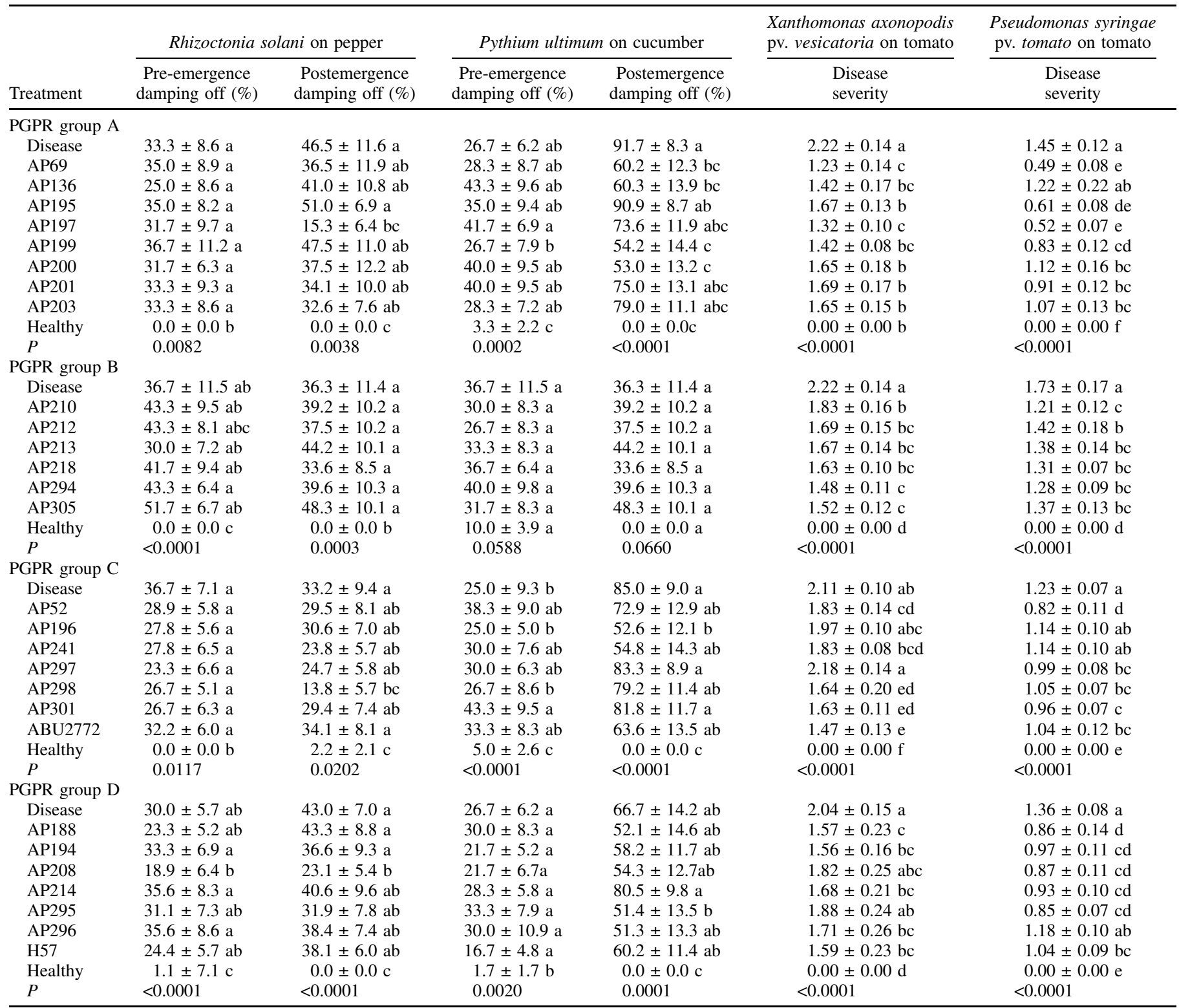

${ }_{\mathrm{z}}$ Values (mean $\pm \mathrm{SE}$ ) in the same column followed by the same letter do not significantly differ based on least square means statement of the GLIMMIX procedure in SAS 9.4 at $P=0.05$. 
plant, and the disease severities of compound leaf were averaged by the disease severity of leaflets on that compound leaf. The leaflet was rated using a 0 to 4 rating scale, where $0=$ healthy leaflet, $1=<20 \%$ necrotic area of leaflet, $2=20$ to $50 \%$ necrotic area of leaflet, $3=51$ to $80 \%$ necrotic area of leaflet, and $4=80$ to $100 \%$ necrotic area of leaflet or fully dead leaflet.

Genome sequencing. Each strain was grown overnight $\left(37^{\circ} \mathrm{C}\right)$ in trypticase soy broth, and genomic DNA was extracted from $2.5 \mathrm{ml}$ of bacterial culture using the E.Z.N.A. bacterial DNA kit (OMEGA Bio-tek, Norcross, GA). Genomic DNA concentration was estimated using a Qubit dsDNA BR assay kit (Thermo Fisher Scientific, Waltham, MA), and 55 to $60 \mathrm{ng}$ of this was used for library preparation using the Nextera DNA sample preparation kit (Illumina, San Diego, CA). Individual strain libraries were pooled resulting in a $15 \mathrm{pM}$ library to which $1 \% \mathrm{PhiX}(12.5 \mathrm{pM})$ was added. Genome sequencing was conducted on an Illumina MiSeq sequencer and generated $2 \times 250$ paired end reads. All reads were trimmed and assembled de novo using the CLC Genomics Workbench (Qiagen, Redwood City, CA) using default settings. Raw sequence data were submitted to the Sequence Read Archive and may be found under accession number PRJNA380484.

Prediction of secondary metabolite biosynthesis gene clusters in broad-spectrum biocontrol PGPR strains. For strains (AP69, AP197, AP199, AP298) selected in the advanced screen and AP305 that is the commercially available strain $B$. subtilis GB03, secondary metabolite biosynthesis gene clusters were predicted via the secondary metabolite identification tool antiSMASH (Blin et al. 2013) using the assembled reads as input. Gene prediction and annotation were carried out by GeneMark and BLASTx (NCBI) (Lukashin and Borodovsky 1998).

Statistical analysis. The data were analyzed in SAS 9.4 software (SAS Institute, Cary, NC) using the PROC GLIMMIX procedure, and treatment means were compared using LSMEANS with the PDIFF option at $P=0.05$ level. Fixed effects were treatments and the random effects included replication and test repeat. Disease severity data were $\log$-transformed $(\log x+1)$, and disease incidence data were arcsine-square-root transformed before data analysis. Student panel graphs were generated and evaluated to determine the normality of the residuals. The original mean values $( \pm \mathrm{SE})$ are presented in the tables with $P$ values to determine statistical differences.

\section{RESULTS}

Preliminary screen. Twenty-eight of the 196 tested PGPR strains inhibited all eight tested pathogens in vitro and were chosen for secondary screen (Table 1). Of the 28 strains, 25 were identified as $B$. velezensis, two strains as $B$. altitudinis, and one strain as Paenibacillus peoriae.

Secondary screen. The selected 28 strains produced inhibition zones against all six tested pathogens (Table 2). Twenty-four of the 28 strains produced all five tested traits related to plant growth

TABLE 5. Summary of suppression of three different pathogens by individual plant growth-promoting rhizobacteria strains in two or three repeated trials

\begin{tabular}{lccccccc}
\hline & \multicolumn{6}{c}{ Mean percentage of disease reduction $(\%)^{\mathrm{z}}$} \\
\cline { 2 - 7 } Strain & Rs-Pre & Rs-Post & Pu-Pre & Pu-Post & Xav & Pto & Total mean \\
\hline AP197 & 4.8 & 67.1 & - & - & 40.5 & 64.1 & 44.1 \\
AP298 & 27.2 & 58.4 & - & - & 22.3 & 14.6 & 30.6 \\
AP69 & - & - & -6.0 & 34.4 & 44.6 & 66.2 & 34.8 \\
AP199 & - & - & 0.0 & 40.9 & 36.0 & 42.8 & 29.9 \\
AP200 & - & - & -49.8 & 42.2 & 25.7 & 22.8 & 10.2 \\
\hline
\end{tabular}

$\mathrm{z}$ Rs-Pre = pre-emergence damping-off of Rhizoctonia solani, Rs-Post = postemergence damping-off of $R$. solani, Pu-Pre = pre-emergence dampingoff of Pythium ultimum, Pu-Post = postemergence damping-off of Pythium ultimum, Xav = Xanthomonas axonopodis pv. vesicatoria, and Pto = Pseudomonas syringae pv. tomato. promotion (Table 3). Presumptive nitrogen fixation was demonstrated by 27 isolates based on formation of a pellicle in the semisolid free-nitrogen medium. In the phosphate solubilization tests, strains solubilized 0.0 to $2.6 \mu \mathrm{g} / \mathrm{ml} \mathrm{Ca}_{3}\left(\mathrm{PO}_{4}\right)_{2}, 0.0$ to $0.1 \mu \mathrm{g} / \mathrm{ml}$ $\mathrm{FePO}_{4}$, and 0.00 to $1.7 \mu \mathrm{g} / \mathrm{ml} \mathrm{AlPO}_{4}$. Twenty-seven strains were positive for siderophore production. The tested strains produced IAA in media supplemented with tryptophan (Trp), at levels of 3.0 to $15.0 \mu \mathrm{g} / \mathrm{ml}$. In the biofilm test, 27 strains formed a pellicle on the surface of the growth medium, which indicated biofilm formation. All 28 tested strains were chosen for advanced screen based on their broad-spectrum biocontrol activity and production of multiple traits related to plant growth promotion.

Advanced screen. No individual PGPR strains significantly inhibited all four different pathogens (Table 4); however, five stains inhibited three out of four tested pathogens. Strains AP197 and AP298 significantly reduced the disease severity of two foliar bacterial diseases on tomato and postemergence damping off caused by $R$. solani on pepper, and treatments AP69, AP199, and AP200 significantly reduced the disease severity of two foliar bacterial diseases on tomato and postemergence damping off caused by Pythium ultimum on cucumber (Table 4). Nineteen individual PGPR strains reduced two out of four diseases (Table 4).

Means of disease reductions of $R$. solani and two foliar bacterial diseases were 41.3 and $30.6 \%$ for strain AP197 and AP298, respectively (Table 5). Strains AP69 and AP199 showed higher percentages of disease suppression compared with strain AP200 for biological control of Pythium ultimum and two foliar bacterial diseases. Means of disease reductions were $34.8 \%$ and $29.9 \%$ for strains AP69 and AP199, respectively, and 10.2\% for AP200. Of the 28 tested strains, four PGPR strains (AP69, AP197, AP199, and AP298) showed the best broad-spectrum biocontrol activity of multiple plant diseases (Table 5).

Secondary metabolite biosynthesis and natural competency in broad-spectrum biocontrol PGPR strains. Figure 1 showed the listing of all genes predicted within a given biosynthesis pathway and the corresponding strain(s) predicted to produce each secondary metabolite. Secondary metabolite biosynthesis gene clusters involved in nonribosomal synthesis of cyclic lipopeptides (NRPS) (bacillibactin and bacilysin), and several gene fragments involved in the PGPR volatile organic compound (terpene), the ribosomally synthesized peptides (microcins) and the type III polyketide synthases were detected in all five tested stains. The presence of NRPS gene clusters encoding fengycin and surfactin, and polyketide synthase (PKS) gene clusters for bacillaene, difficidin and macrolactin in four tested strains (AP197, AP199, AP298, and AP305) were also detected. Butirosin, a clinically valuable antibiotic found in $B$. circulans was detected in strains AP197 and AP199 (Llewellyn et al. 2007). One NRPS (plipastatin also known as fengycin A and B) was detected in strains AP298 and AP305, and the published strain B. subtilis 168 (Hussein and Fahim 2015). Strain AP69 produced several additional secondary metabolites, including carotenoid, lichenysin, paenilamicin, sporulation killing factor, and welwitindolinone. Gene clusters for the ladderane and ribosomally synthetized peptide (mersacidin) were also detected in strain AP305. A very common NRPS gene cluster of bacillomycin was found in strain AP298. For each predicted secondary metabolite gene cluster, BLASTx analysis revealed all predicted open reading frames to be $\geq 97 \%$ similar to known genes within the predicted secondary metabolite biosynthesis pathway.

\section{DISCUSSION}

The overall results of this study demonstrate that some single PGPR strains exhibit both broad-spectrum biocontrol activity and production of multiple traits related to plant growth promotion in vitro. Twenty-four of twenty-eight elite PGPR strains selected in the preliminary screen inhibited all six genera of pathogens tested in the 
secondary antibiosis test and produced all five tested traits related to plant growth promotion. Some PGPR strains have previously been reported to produce multiple traits related to plant growth promotion and biological control (Bakthavatchalu et al. 2012; Wahyudi and Astuti 2011); however, the PGPR strains in those studies were all Pseudomonas spp. and were only tested for antibiosis against fungal pathogens. In contrast, in the current study, a total of 10 pathogens, belonging to six different genera, were used in preliminary and secondary antibiosis tests, and these included bacterial and fungal pathogens. In addition, the tested pathogens included foliar pathogens, vascular pathogens, and root pathogens. The results demonstrated that the elite PGPR strains had a broad biocontrol activity that could help in plant establishment and resisting against pathogens under field conditions.

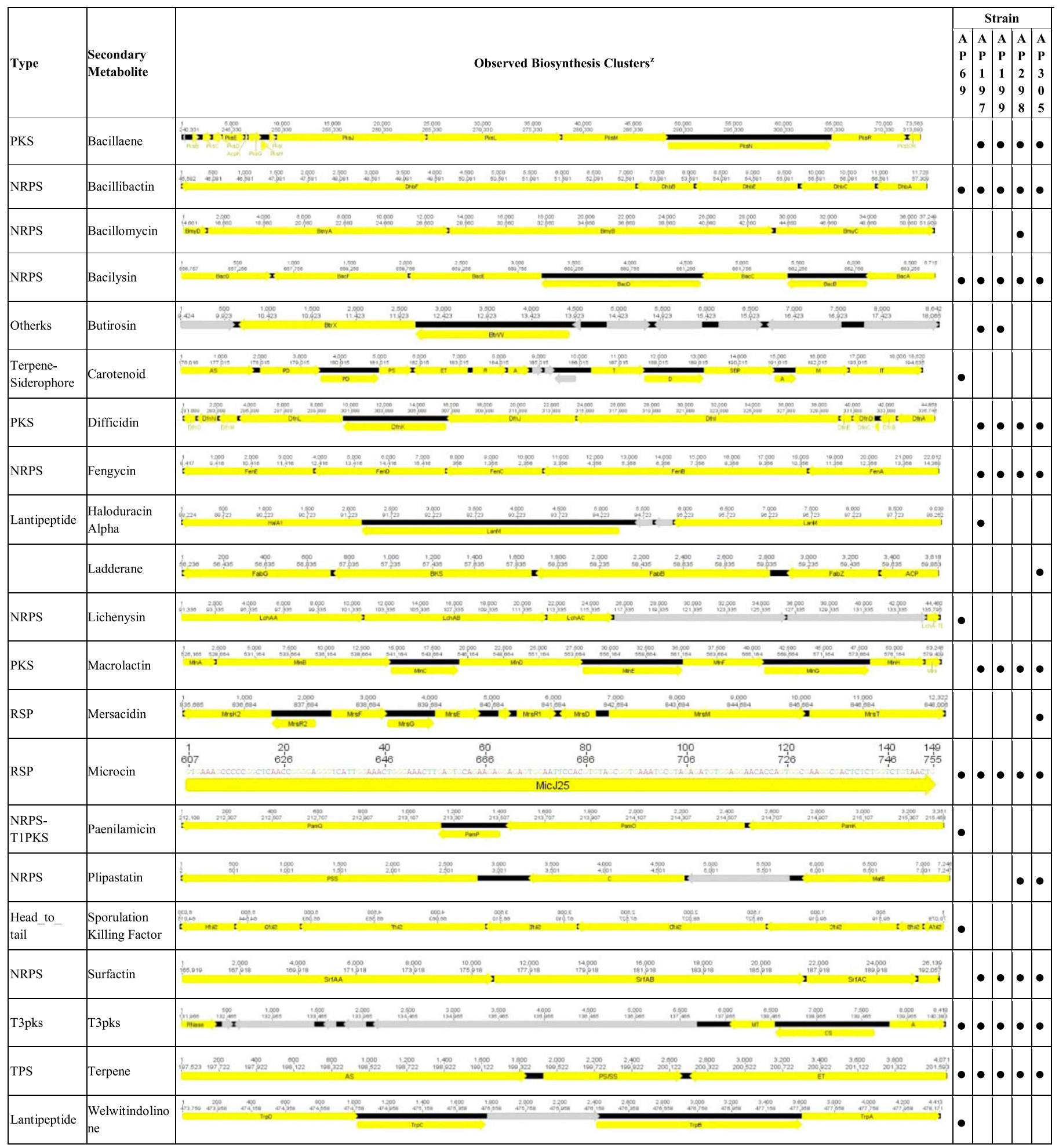

Fig. 1. Listing of secondary metabolites predicted by antiSMASH to be produced by the tested strains. All yellow open reading frames (ORFs) were found within the noted strains and identified by BLASTx 27 as sharing 97\% sequence identity to the protein listed, unless otherwise noted. All gray ORFs represent ORFs present that did not match known proteins involved in the synthesis of the listed metabolite. $\mathrm{A}=$ acetyltransferase, $\mathrm{ACP}=$ acyl 30 carrier protein, $\mathrm{AS}=$ asparagine synthetase, $\mathrm{BKS}=$ beta-ketoacyl synthase, $\mathrm{C}=$ carboxypeptidase, $\mathrm{CS}=$ chalcone synthase, $\mathrm{D}=$ decarboxylase, $\mathrm{ET}=$ efflux transporter, IT $=$ iron transporter, $\mathrm{M}=$ monooxygenase, $\mathrm{MT}=$ multidrug transporter, $\mathrm{PD}=$ phytoene desaturase, $\mathrm{PS}=$ phytoene synthase, $\mathrm{PSS}=$ plipastatin synthase subunit, $\mathrm{SBP}=$ siderophore biosynthesis protein, $\mathrm{SS}=$ squalene synthase, $\mathrm{T}=$ transaminase, and $\mathrm{R}=$ transcriptional regulator. 
TABLE 6. List of plant growth-promoting rhizobacteria strains showing broad-spectrum biocontrol capacity

\begin{tabular}{|c|c|c|c|c|c|}
\hline $\mathrm{Rs}+\mathrm{Pu}+\mathrm{Xav}+\mathrm{Pto}^{\mathrm{z}}$ & $\mathrm{Rs}+\mathrm{Xav}+\mathrm{Pto}$ & $\mathrm{Pu}+\mathrm{Xav}+\mathrm{Pto}$ & $\mathrm{Xav}+\mathrm{Pto}$ & $\mathrm{Pu}+\mathrm{Xav}$ & Rs+Pto \\
\hline (0 strains) & AP197 and AP298 & AP69, AP199, and AP200 & $\begin{array}{c}\text { AP52, AP188, AP194, AP195, AP201, } \\
\text { AP203, AP210, AP212, AP213, AP214, } \\
\text { AP218, AP294, AP301, AP305, and } \\
\text { ABU2772 } \\
\text { (15 strains })\end{array}$ & (1 strain) & (1 strain) \\
\hline
\end{tabular}

${ }^{\mathrm{z}} \mathrm{Rs}=$ Rhizoctonia solani, $\mathrm{Pu}=$ Pythium ultimum, Xav = Xanthomonas axonopodis pv. vesicatoria, and Pto = Pseudomonas syringae pv. tomato.

B. velezensis which has previously been identified to the B. amyloliquefaciens group exhibited the best broad-spectrum biocontrol activity when compared with other species in this collection. Of the 196 spore-forming bacilli strains tested in the current study, 184 strains were identified as 15 species of Bacillus including B. cereus (37 strains), B. simplex (34 strains), B. velezensis (28 strains), B. megaterium (25 strains), B. stratosphericus (15 strains), B. safensis (14 strains), B. mycoides (10 strains), B. subtilis (8 strains), B. altitudinis (4 strains), B. solisalsi (3 strains), $B$. aerophilus (1 strain), B. mojavensis (1 strain), B. aerophilus (1 strain), B. nealsonii (1 strain), B. psychrosaccharolyticus (1 strain), and $B$. vireti (1 strain) (data not shown). Of the 28 strains that inhibited all eight tested pathogens in the preliminary screen, 25 strains belonged to $B$. velezensis, while another two strains belonged to $B$. altitudinis, and one strain was Paenibacillus peoriae. Therefore, B. velezensis, which had previously been identified to the $B$. amyloliquefaciens group, is widely recognized as an efficient biocontrol agent (Balhara et al. 2011).

Some individual PGPR strains can provide biological control against multiple plant diseases on different hosts through the mechanism of antagonism. Specifically, from the growth chamber trials, five individual PGPR stains significantly reduced three of the four tested diseases, and 19 individual PGPR strains inhibited two of the four tested diseases (Table 6). These results are in agreement with previous studies in which individual PGPR strains Pseudomonas putida 89B-27 and Serratia marcescens 90-166 exhibited biological control of anthracnose caused by Colletotrichum orbiculare (Wei et al. 1991), Fusarium wilt caused by F. oxysporum f. sp. cucumerinum (Liu et al. 1995a), bacterial angular leaf spot caused by Pseudomonas syringae pv. lachrymans (Liu et al. 1995b), and cucurbit wilt caused by E. tracheiphila (Kloepper et al. 1997). However, the mechanism by which strains 89B-27 and 90-166 provide biological control was induced systemic resistance (ISR), in which PGPR activate plant defenses which can lead to protection against multiple plant diseases (Zehnder et al. 2001), while antagonism was the mechanism in the current study. A significant amount of research on antagonism has been conducted in studies on the biological control of phytopathogens that infect major crops (Beneduzi et al. 2012; Liu et al. 2009), fruits (Droby et al. 1989; Li et al. 2011), and vegetables (Pernezny et al. 1996; Sharma et al. 2009). In most studies, antagonists were selected against a single target pathogen, resulting in control of only one or two diseases in vivo (Baker and Cook 1974). Some antagonists have been defined as broadspectrum candidates based only on in vitro tests (Köberl et al. 2013; Kumar et al. 2012; Wahyudi and Astuti 2011). Our data suggest that like ISR, antagonism is an effective way for individual PGPR strains to exhibit biological control against multiple plant diseases.

Our results further suggest that some PGPR strains can survive both in the rhizosphere and on the phylloplane, because disease protection occurred against both soilborne and foliar pathogens. Five individual PGPR stains (AP69, AP197, AP199, AP200, and AP298) reduced the disease severity of bacteria rot and bacteria speck through foliar application, and also reduced the disease incidence of post-damping off of cucumber or pepper through seed treatment. Similar findings were reported in previous studies with
P. fluorescens strain Pf7-14 applied as a seed treatment and foliar spray for biological control of rice blast (Krishnamurthy and Gnanamanickam 1998) and P. fluorescens strain Pf1 applied on the rhizosphere and phylloplane for biological control of late leaf spot disease of groundnut (Meena 2010). In the current study, sporeforming Bacillus spp. strains were used, and the same PGPR strain colonized multiple hosts, while in previous studies PGPR strains colonized a single host. Colonization of the phylloplane and rhizosphere are different processes. Phylloplane colonization is considered to be more difficult due to the limitation of nutrients and exposure to the harsh environment of the leaf surface (Andrews 1992). Hence, PGPR are most often used as seed treatments on crops against soilborne fungi and nematodes following colonization of the rhizosphere (Abbasi et al. 2011; Hashem and Abo-Elyousr 2011; Sikora 1992; Xiang et al. 2016), but some PGPR have also been shown to be effective as foliar application to control foliar diseases by multiple foliar applications ( $\mathrm{Ji}$ et al. 2006). More extensive studies are needed to characterize the rhizosphere and phylloplane colonization patterns for the five PGPR strains selected in the current study.

The wide biocontrol range of the selected four individual PGPR strains to three pathogens in this study is striking, suggesting a complicated mechanism of action that may involve more than one metabolite as reported previously (Howell 1982; Lumsden and Locke 1989). In our study, genes encoding for bacillibactin, bacilysin, and microcin were detected in all four selected strains. Bacillaene, difficidin, fengycin, macrolactin, and surfactin were also found in three of these strains (AP197, AP199, and AP298). All these predicted secondary metabolites except bacillibactin and macrolactin were detected in the published strains B. amyloliquesfaciens FZB42 (Chen et al. 2007), B. amyloliquesfaciens GA1 (Arguelles-Arias et al. 2009), B. amyloliquesfaciens subsp. plantarum AP193 (Hossain et al. 2015), and B. subtilis 168 (Kunst et al. 1997). Bacillibactin was detected in strains B. amyloliquesfaciens FZB42, B. amyloliquesfaciens $\mathrm{GA} 1$, and B. subtilis 168 , while macrolactin was detected in strains $B$. amyloliquesfaciens FZB42, B. amyloliquesfaciens subsp. plantarum AP193, and B. amyloliquesfaciens GA1. These published strains showed a wide antagonistic activity against phytopathogens. For example, strain B. amyloliquefaciens FZB42 showed biological control of bacteria (Wu et al. 2015), fungi (Cawoy et al. 2015), and nematodes (Burkett-Cadena et al. 2008). In our study, theses selected four individual PGPR strains controlled one fungal disease and two bacterial diseases.

In summary, the results reported here showed that selected individual PGPR strains showed broad-spectrum biocontrol activity to multiple plant diseases. In the future, it may be possible to apply mixtures of selected PGPR strains and check whether the mixtures of PGPR will improve the control efficiency compared with individual PGPR strains.

\section{ACKNOWLEDGMENTS}

We thank L. Carter for technical assistance. We acknowledge support from the USDA/NIFA Hatch program. 


\section{LITERATURE CITED}

Abbasi, M., Sharif, S., Kazmi, M., Sultan, T., and Aslam, M. 2011. Isolation of plant growth promoting rhizobacteria from wheat rhizosphere and their effect on improving growth, yield and nutrient uptake of plants. Plant Biosyst. 145:159-168.

Ahmad, F., Ahmad, I., and Khan, M. 2008. Screening of free-living rhizospheric bacteria for their multiple plant growth promoting activities. Microbiol. Res. 163:173-181.

Alexander, D. B., and Zuberer, D. A. 1991. Use of chrome azurol-S reagents to evaluate siderophore production by rhizosphere bacteria. Biol. Fertil. Soils 12:39-45.

Andrews, J. H. 1992. Biological control in the phyllosphere. Annu. Rev. Phytopathol. 30:603-635.

Arguelles-Arias, A., Ongena, M., Halimi, B., Lara, Y., Brans, A., Joris, B., and Fickers, P. 2009. Bacillus amyloliquefaciens GA1 as a source of potent antibiotics and other secondary metabolites for biocontrol of plant pathogens. Microbiol. Cell Fact. 8:63.

Baker, K., and Cook, R. J. 1974. Biological Control of Plant Pathogens. WH Freeman and Company, San Francisco.

Bakthavatchalu, S., Shivakumar, B., and Sullia, S. B. 2012. Identification of multi-trait PGPR isolates and evaluation of their potential as biocontrol agents. Acta Biol. Indica 1:61-67.

Balhara, M., Ruhil, S., Dhankhar, S., and Chhillar, K. A. 2011. Bioactive compounds hold up Bacillus amyloliquefaciens as a potent bio-control agent. Nat. Prod. J. 1:20-28.

Bashan, Y., Kamnev, A. A., and de-Bashan, L. E. 2013. Tricalcium phosphate is inappropriate as a universal selection factor for isolating and testing phosphate-solubilizing bacteria that enhance plant growth: A proposal for an alternative procedure. Biol. Fertil. Soils 49:465-479.

Beneduzi, A., Ambrosini, A., and Passaglia, L. M. 2012. Plant growthpromoting rhizobacteria (PGPR): Their potential as antagonists and biocontrol agents. Genet. Mol. Biol. 35:1044-1051.

Bhattacharjee, R. B., Singh, A., and Mukhopadhyay, S. 2008. Use of nitrogenfixing bacteria as biofertiliser for non-legumes: Prospects and challenges. Appl. Microbiol. Biotechnol. 80:199-209.

Blin, K., Medema, M. H., Kazempour, D., Fischbach, M. A., Breitling, R., Takano, E., and Weber, T. 2013. antiSMASH 2.0_A versatile platform for genome mining of secondary metabolite producers. Nucleic Acids Res. 41: W204-W212.

Burkett-Cadena, M., Kokalis-Burelle, N., Lawrence, K. S., van Santen, E., and Kloepper, J. W. 2008. Suppressiveness of root-knot nematodes mediated by rhizobacteria. Biol. Control 47:55-59.

Cawoy, H., Debois, D., Franzil, L., De Pauw, E., Thonart, P., and Ongena, M. 2015. Lipopeptides as main ingredients for inhibition of fungal phytopathogens by Bacillus subtilis/amyloliquefaciens. Microbiol. Biotechnol. 8: 281-295.

Chen, X. H., Koumoutsi, A., Scholz, R., Eisenreich, A., Schneider, K., Heinemeyer, I., Morgenstern, B., Voss, B., Hess, W. R., Reva, O., Junge, H., Voigt, B., Jungblut, P. R., Vater, J., Sussmuth, R., Liesegang, H., Strittmatter, A., Gottschalk, G., and Borriss, R. 2007. Comparative analysis of the complete genome sequence of the plant growth-promoting bacterium Bacillus amyloliquefaciens FZB42. Nat. Biotechnol. 25:1007-1014.

D'aes, J., Hua, G. K. H., De Maeyer, K., Pannecoucque, J., Forrez, I., Ongena, M., Dietrich, L. E., Thomashow, L. S., Mavrodi, D. V., and Höfte, M. 2011. Biological control of Rhizoctonia root rot on bean by phenazine-and cyclic lipopeptide-producing Pseudomonas CMR12a. Phytopathology 101:996-1004.

Deleu, M., Paquot, M., and Nylander, T. 2008. Effect of fengycin, a lipopeptide produced by Bacillus subtilis, on model biomembranes. Biophys. J. 94:2667-2679.

Droby, S., Chalutz, E., Wilson, C. L., and Wisniewski, M. 1989. Characterization of the biocontrol activity of Debaryomyces hansenii in the control of Penicillium digitatum on grapefruit. Can. J. Microbiol. 35:794-800.

Dunham, W. C. 2016. Global Biologicals Market Update March 2016_BPIA. DunhamTrimmer International Bio Intelligence.

Dunlap, C. A., Kim, S.-J., Kwon, S.-W., and Rooney, A. P. 2016. Bacillus velezensis is not a later heterotypic synonym of Bacillus amyloliquefaciens; Bacillus methylotrophicus, Bacillus amyloliquefaciens subsp. plantarum and Bacillus oryzicola are later heterotypic synonyms of Bacillus velezensis based on phylogenomics. Int. J. Syst. Evol. Microbiol. 66:1212-1217.

Fatima, Z., Saleemi, M., Zia, M., Sultan, T., Aslam, M., Rehman, R., and Chaudhary, M. F. 2009. Antifungal activity of plant growth-promoting rhizobacteria isolates against Rhizoctonia solani in wheat. Afr. J. Biotechnol. 8:219-225.

Gordon, S. A., and Weber, R. P. 1951. Colorimetric estimation of indoleacetic acid. Plant Physiol. 26:192-195.

Gupta, G., Parihar, S. S., Ahirwar, N. K., Snehi, S. K., and Singh, V. 2015. Plant growth promoting rhizobacteria (PGPR): Current and future prospects for development of sustainable agriculture. J. Microbiol. Biochem. Technol. 7:96-102.

Hamon, M. A., and Lazazzera, B. A. 2001. The sporulation transcription factor Spo0A is required for biofilm development in Bacillus subtilis. Mol. Microbiol. 42:1199-1209.

Hashem, M., and Abo-Elyousr, K. A. 2011. Management of the root-knot nematode Meloidogyne incognita on tomato with combinations of different biocontrol organisms. Crop Prot. 30:285-292.

Hossain, M. J., Ran, C., Liu, K., Ryu, C. M., Rasmussen-Ivey, C. R., Williams, M. A., Hassan, M. K., Choi, S. K., Jeong, H., Newman, M., Kloepper, J. W., and Liles, M. R. 2015. Deciphering the conserved genetic loci implicated in plant disease control through comparative genomics of Bacillus amyloliquefaciens subsp. plantarum. Front. Plant Sci. 6:631.

Howell, C. 1982. Effect of Gliocladium virens on Pythium ultimum, Rhizoctonia solani, and damping-off of cotton seedlings. Phytopathology 72:496498.

Howell, C. R. 2007. Effect of seed quality and combination fungicide-Trichoderma spp. seed treatments on pre- and postemergence damping-off in cotton. Phytopathology 97:66-71.

Hussein, W., and Fahim, S. 2015. Modification of wild type Bacillus subtilis 168 strain for single surfactin production. Int. J. Curr. Microbiol. App. Sci 4:177-184.

Idris, E. E., Iglesias, D. J., Talon, M., and Borriss, R. 2007. Tryptophandependent production of indole-3-acetic acid (IAA) affects level of plant growth promotion by Bacillus amyloliquefaciens FZB42. Mol. PlantMicrobe Interact. 20:619-626.

Ji, P., Campbell, H. L., Kloepper, J. W., Jones, J. B., Suslow, T. V., and Wilson, M. 2006. Integrated biological control of bacterial speck and spot of tomato under field conditions using foliar biological control agents and plant growth-promoting rhizobacteria. Biol. Control 36:358-367.

Kloepper, J. W., Tuzun, S., Zehnder, G. W., and Wei, G. 1997. Multiple disease protection by rhizobacteria that induce systemic resistance-historical precedence. Phytopathology 87:136-137.

Köberl, M., Ramadan, E. M., Adam, M., Cardinale, M., Hallmann, J., Heuer, H., Smalla, K., and Berg, G. 2013. Bacillus and Streptomyces were selected as broad-spectrum antagonists against soilborne pathogens from arid areas in Egypt. FEMS Microbiol. Lett. 342:168-178.

Krishnamurthy, K., and Gnanamanickam, S. 1998. Biological control of rice blast by Pseudomonas fluorescens strain Pf7-14: Evaluation of a marker gene and formulations. Biol. Control 13:158-165.

Kumar, P., Dubey, R. C., and Maheshwari, D. K. 2012. Bacillus strains isolated from rhizosphere showed plant growth promoting and antagonistic activity against phytopathogens. Microbiol. Res. 167:493-499.

Kunst, F., Ogasawara, N., Moszer, I., Albertini, A. M., Alloni, G., Azevedo, V., Bertero, M. G., Bessieres, P., Bolotin, A., Borchert, S., Borriss, R., Boursier, L., Brans, A., Braun, M., Brignell, S. C., Bron, S., Brouillet, S., Bruschi, C. V., Caldwell, B., Capuano, V., Carter, N. M., Choi, S. K., Codani, J. J., Connerton, I. F., Cummings, N. J., Daniel, R. A., Denizot, F., Devine, K. M., Dusterhoft, A., Ehrlich, S. D., Emmerson, P. T., Entian, K. D., Errington, J., Fabret, C., Ferrari, E., Foulger, D., Fritz, C., Fujita, M., Fujita, Y., Fuma, S., Galizzi, A., Galleron, N., Ghim, S. Y., Glaser, P., Goffeau, A., Golightly, E. J., Grandi, G., Guiseppi, G., Guy, B. J., Haga, K., Haiech, J., Harwood, C. R., Henaut, A., Hilbert, H., Holsappel, S., Hosono, S., Hullo, M. F., Itaya, M., Jones, L., Joris, B., Karamata, D., Kasahara, Y., Klaerr-Blanchard, M., Klein, C., Kobayashi, Y., Koetter, P., Koningstein, G., Krogh, S., Kumano, M., Kurita, K., Lapidus, A., Lardinois, S., Lauber, J., Lazarevic, V., Lee, S. M., Levine, A., Liu, H., Masuda, S., Mauel, C., Medigue, C., Medina, N., Mellado, R. P., Mizuno, M., Moestl, D., Nakai, S., Noback, M., Noone, D., OReilly, M., Ogawa, K., Ogiwara, A., Oudega, B., Park, S. H., Parro, V., Pohl, T. M., Portetelle, D., Porwollik, S., Prescott, A. M., Presecan, E., Pujic, P., Purnelle, B., Rapoport, G., Rey, M., Reynolds, S., Rieger, M., Rivolta, C., Rocha, E., Roche, B., Rose, M., Sadaie, Y., Sato, T., Scanlan, E., Schleich, S., Schroeter, R., Scoffone, F., Sekiguchi, J., Sekowska, A., Seror, S. J., Serror, P., Shin, B. S., Soldo, B., Sorokin, A., Tacconi, E., Takagi, T., Takahashi, H., Takemaru, K., Takeuchi, M., Tamakoshi, A., Tanaka, T., Terpstra, P., Tognoni, A., Tosato, V., Uchiyama, S., Vandenbol, M., Vannier, F., Vassarotti, A., Viari, A., Wambutt, R., Wedler, E., Wedler, H., Weitzenegger, T., Winters, P., Wipat, A., Yamamoto, H., Yamane, K., Yasumoto, K., Yata, K., Yoshida, K., Yoshikawa, H. F., Zumstein, E., Yoshikawa, H., and Danchin, A. 1997. The complete genome sequence of the Gram-positive bacterium Bacillus subtilis. Nature 390:249-256.

Li, H., Li, H., Bai, Y., Wang, J., Nie, M., Li, B., and Xiao, M. 2011. The use of Pseudomonas fluorescens P13 to control Sclerotinia stem rot (Sclerotinia sclerotiorum) of oilseed rape. J. Microbiol. 49:884-889.

Liu, B., Qiao, H., Huang, L., Buchenauer, H., Han, Q., Kang, Z., and Gong, Y. 2009. Biological control of take-all in wheat by endophytic Bacillus subtilis E1R-j and potential mode of action. Biol. Control 49:277-285. 
Liu, K., Garrett, C., Fadamiro, H., and Kloepper, J. W. 2016. Induction of systemic resistance in Chinese cabbage against black rot by plant growthpromoting rhizobacteria. Biol. Control 99:8-13.

Liu, L., Kloepper, J., and Tuzun, S. 1995a. Induction of systemic resistance in cucumber against Fusarium wilt by plant growth-promoting rhizobacteria. Phytopathology 85:695-698.

Liu, L., Kloepper, J., and Tuzun, S. 1995b. Induction of systemic resistance in cucumber against bacterial angular leaf spot by plant growth-promoting rhizobacteria. Phytopathology 85:843-847.

Llewellyn, N. M., Li, Y. Y., and Spencer, J. B. 2007. Biosynthesis of butirosin: Transfer and deprotection of the unique amino acid side chain. Chem. Biol. 14:379-386.

Lugtenberg, B. 2014. Principles of Plant-Microbe Interactions: Microbes For Sustainable Agriculture. Springer International Publishing, Switzerland

Lukashin, A. V., and Borodovsky, M. 1998. GeneMark.hmm: New solutions for gene finding. Nucleic Acids Res. 26:1107-1115.

Lumsden, R., and Locke, J. 1989. Biological control of damping-off caused by Pythium ultimum and Rhizoctonia solani with Gliocladium virens in soilless mix. Phytopathology 79:361-366.

McCullagh, M., Utkhede, R., Menzies, J. G., Punja, Z. K., and Paulitz, T. C. 1996. Evaluation of plant growth-promoting rhizobacteria for biological control of Pythium root rot of cucumbers grown in rockwool and effects on yield. Eur. J. Plant Pathol. 102:747-755.

Meena, B. 2010. Effect of Pseudomonas fluorescens Pf1 formulation application on rhizosphere and phyllosphere population in groundnut. Int. J. Plant Prod. 4:92-94

Murphy, J., and Riley, J. P. 1962. A modified single solution method for the determination of phosphate in natural waters. Anal. Chim. Acta 27:31-36.

Nasrin, S., Hossain, M. J., and Liles, M. R. 2015. Draft genome sequence of Bacillus amyloliquefaciens AP183 with antibacterial activity against methicillin-resistant Staphylococcus aureus. Genome Announc. 3:e00162-15.

Nelson, B. A., Ramaiya, P., de Leon, A. L., Kumar, R., Crinklaw, A., Jolkovsky, E., Crane, J. M., Bergstrom, G. C., and Rey, M. W. 2014. Complete genome sequence for the Fusarium head blight antagonist $\mathrm{Ba}$ cillus amyloliquefaciens strain TrigoCor 1448. Genome Announc. 2: e00219-14.

O’Toole, G. A., Pratt, L. A., Watnick, P. I., Newman, D. K., Weaver, V. B., and Kolter, R. 1999. Genetic approaches to study of biofilms. Pages 91-109 in: Methods in Enzymology. Vol. 310. J. N. Abelson, M. I. Simon, and R. J. Doyle, eds. Academic Press, San Diego, CA.

Olivares, F. L., Baldani, V. L. D., Reis, V. M., Baldani, J. I., and Dobereiner, J. 1996. Occurrence of the endophytic diazotrophs Herbaspirillum spp. in roots, stems, and leaves, predominantly of Gramineae. Biol. Fertil. Soils 21:197-200.

Pernezny, K., Datnoff, L. E., Mueller, T., and Collins, J. 1996. Losses in freshmarket tomato production in Florida due to target spot and bacterial spot and the benefits of protectant fungicides. Plant Dis. 80:559-563.

Praveen Kumar, G., Mir Hassan Ahmed, S. K., Desai, S., Leo Daniel Amalraj, E., and Rasul, A. 2014. In vitro screening for abiotic stress tolerance in potent biocontrol and plant growth promoting strains of Pseudomonas and Bacillus spp. Int. J. Bacteriol. 2014:195946.

Saharan, B., and Nehra, V. 2011. Plant growth promoting rhizobacteria: A critical review. Life Sci. Med. Res. 21:1-30.

Sayyed, R., Chincholkar, S., Reddy, M., Gangurde, N., and Patel, P. 2013. Siderophore producing PGPR for crop nutrition and phytopathogen suppression. Pages 449-471 in: Bacteria in Agrobiology: Disease Management. D. K. Maheshwari, ed. Springer, New York.

Seneviratne, G., Weerasekara, M., Seneviratne, K., Zavahir, J., Kecskés, M., and Kennedy, I. 2011. Importance of biofilm formation in plant growth promoting rhizobacterial action. Pages 81-95 in: Plant Growth and Health Promoting Bacteria. D. K. Maheshwari, ed. Springer, Berlin, Heidelberg.

Sharma, R., Singh, D., and Singh, R. 2009. Biological control of postharvest diseases of fruits and vegetables by microbial antagonists: A review. Biol. Control 50:205-221.

Sikora, R. A. 1992. Management of the antagonistic potential in agricultural ecosystems for the biological control of plant parasitic nematodes. Annu. Rev. Phytopathol. 30:245-270.

Stabb, E. V., Jacobson, L. M., and Handelsman, J. 1994. Zwittermicin Aproducing strains of Bacillus cereus from diverse soils. Appl. Environ. Microbiol. 60:4404-4412.

Wahyudi, A., and Astuti, R. 2011. Screening of Pseudomonas sp. isolated from rhizosphere of soybean plant as plant growth promoter and biocontrol agent. Am. J. Agric. Biol. Sci. 6:134-141.

Wei, G., Kloepper, J. W., and Tuzun, S. 1991. Induction of systemic resistance of cucumber to Colletotrichum orbiculare by select strains of plant growthpromoting rhizobacteria. Phytopathology 81:1508-1512.

Wu, L. M., Wu, H. J., Chen, L., Yu, X. F., Borriss, R., and Gao, X. W. 2015. Difficidin and bacilysin from Bacillus amyloliquefaciens FZB42 have antibacterial activity against Xanthomonas oryzae rice pathogens. Sci. Rep-Uk 5.

Xiang, N., Lawrence, K. S., Kloepper, J. W., Donald, P. A., McInroy, J. A., and Lawrence, G. W. 2016. Biological control of Meloidogyne incognita by spore-forming plant growth-promoting rhizobacteria on cotton. Plant Dis. 5:774-784.

Yazdani, M., Bahmanyar, M. A., Pirdashti, H., and Esmaili, M. A. 2009. Effect of phosphate solubilization microorganisms (PSM) and plant growthpromoting rhizobacteria (PGPR) on yield and yield components of corn (Zea mays L.). World Acad. Sci. Eng. Technol. 37:90-92.

Yu, G. Y., Sinclair, J. B., Hartman, G. L., and Bertagnolli, B. L. 2002. Production of iturin A by Bacillus amyloliquefaciens suppressing Rhizoctonia solani. Soil Biol. Biochem. 34:955-963.

Yuan, J., Ruan, Y., Wang, B., Zhang, J., Waseem, R., Huang, Q., and Shen, Q. 2013. Plant growth-promoting rhizobacteria strain Bacillus amyloliquefaciens NJN-6-enriched bio-organic fertilizer suppressed Fusarium wilt and promoted the growth of banana plants. J. Agric. Food Chem. 61:3774-3780.

Zehnder, G., Murphy, J., Sikora, E., and Kloepper, J. 2001. Application of rhizobacteria for induced resistance. Eur. J. Plant Pathol. 107:39-50.

This article was modified on 12 Dec 2019. 


\section{ERRATUM / Volume 107, Number 8, 2017 / PHYTO-02-17-0051-R}

In the article "Selection and Assessment of Plant Growth-Promoting Rhizobacteria for Biological Control of Multiple Plant Diseases" by K. Liu, M. Newman, J. A. McInroy, C.-H. Hu, and J. W. Kloepper, strains AP198 and AP211 have been removed from the Xav+Pto column in Table 6. The correct strains are shown below in revised Table 6.

TABLE 6. List of plant growth-promoting rhizobacteria strains showing broad-spectrum biocontrol capacity

\begin{tabular}{|c|c|c|c|c|c|}
\hline $\mathrm{Rs}+\mathrm{Pu}+\mathrm{Xav}+\mathrm{Pto}^{\mathrm{z}}$ & Rs+Xav+Pto & $\mathrm{Pu}+\mathrm{Xav}+\mathrm{Pto}$ & $\mathrm{Xav}+$ Pto & $\mathrm{Pu}+\mathrm{Xav}$ & Rs+Pto \\
\hline (0 strains) & AP197 and AP298 & AP69, AP199, and AP200 & $\begin{array}{c}\text { AP52, AP188, AP194, AP195, AP201, } \\
\text { AP203, AP210, AP212, AP213, AP214, } \\
\text { AP218, AP294, AP301, AP305, and } \\
\text { ABU2772 } \\
(15 \text { strains })\end{array}$ & (1 strain) & (1 strain) \\
\hline
\end{tabular}

${ }^{\mathrm{z}} \mathrm{Rs}=$ Rhizoctonia solani, $\mathrm{Pu}=$ Pythium ultimum, $\mathrm{Xav}=$ Xanthomonas axonopodis pv. vesicatoria, and Pto $=$ Pseudomonas syringae pv. tomato. 